\title{
Rectal Balloon
}

National Cancer Institute

\section{Source}

National Cancer Institute. Rectal Balloon. NCI Thesaurus. Code C104992.

An air filled rectal balloon that is used for prostate immobilization in patients receiving radiation therapy for prostate cancer. 